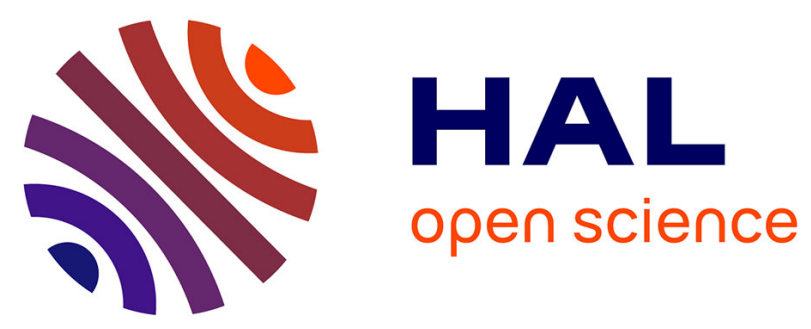

\title{
RURAL DEVELOPMENT AND LABOUR SUPPLY CHALLENGES IN THE UK: THE ROLE OF NON-UK MIGRANTS
}

\author{
Anne Green, Maria de Hoyos, David Owen, Paul Jones
}

\section{- To cite this version:}

Anne Green, Maria de Hoyos, David Owen, Paul Jones. RURAL DEVELOPMENT AND LABOUR SUPPLY CHALLENGES IN THE UK: THE ROLE OF NON-UK MIGRANTS. Regional Studies, 2009, 43 (10), pp.1261-1273. 10.1080/00343400801932318 . hal-00538016

\section{HAL Id: hal-00538016 https://hal.science/hal-00538016}

Submitted on 20 Nov 2010

HAL is a multi-disciplinary open access archive for the deposit and dissemination of scientific research documents, whether they are published or not. The documents may come from teaching and research institutions in France or abroad, or from public or private research centers.
L'archive ouverte pluridisciplinaire $\mathbf{H A L}$, est destinée au dépôt et à la diffusion de documents scientifiques de niveau recherche, publiés ou non, émanant des établissements d'enseignement et de recherche français ou étrangers, des laboratoires publics ou privés. 


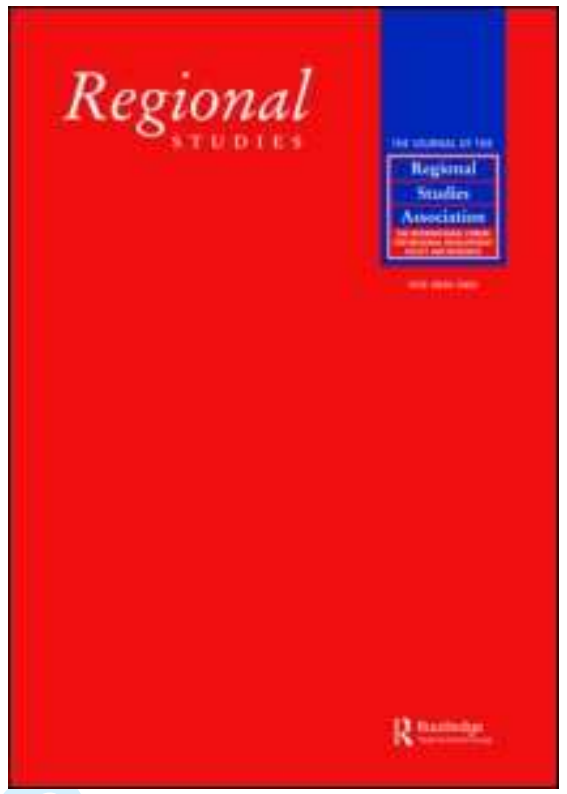

\section{RURAL DEVELOPMENT AND LABOUR SUPPLY CHALLENGES IN THE UK: THE ROLE OF NON-UK MIGRANTS}

\begin{tabular}{|r|l|}
\hline Journal: & Regional Studies \\
\hline Manuscript ID: & CRES-2007-0133.R1 \\
\hline Manuscript Type: & Main Section \\
\hline JEL codes: & $\begin{array}{l}\text { J24 - Human Capital|Skills|Occupational Choice|Labor Productivity } \\
<\text { J2 - Time Allocation, Work Behavior, and Employment } \\
\text { Determination/Creation < J - Labor and Demographic Economics, } \\
\text { J61 - Geographic Labor Mobility|Immigrant Workers < J6 - Mobility, } \\
\text { Economics, R11 - Regional Economic Activity: Growth, } \\
\text { Development, and Changes < R1 - General Regional Economics < R } \\
\text { - Urban, Rural, and Regional Economics, R23 - Regional } \\
\text { Migration|Regional Labor Markets|Population < R2 - Household } \\
\text { Analysis < R - Urban, Rural, and Regional Economics }\end{array}$ \\
\hline Keywords: & \begin{tabular}{l} 
Migration, Skills, Labour market, Rural economic development \\
\hline
\end{tabular} \\
\hline \hline
\end{tabular}

\section{SCHOLARONE" Manuscripts}


1

2

3

RURAL DEVELOPMENT AND LABOUR SUPPLY CHALLENGES IN THE UK: THE ROLE OF NON-UK MIGRANTS

Anne E. Green, Institute for Employment Research, University of Warwick, Coventry CV4 7AL

email: A.E.Green@warwick.ac.uk

Maria de Hoyos, Institute for Employment Research, University of Warwick, Coventry CV4 7AL

email: Maria.de-Hoyos@warwick.ac.uk

Paul Jones, Faculty of Development and Society, Sheffield Hallam University, Howard Street, Sheffield S1 1WB

Email: P.Jones@shu.ac.uk

David Owen, Centre for Research in Ethnic Relations and Institute for Employment Research, University of Warwick, Coventry CV4 7AL

email: D.W.Owen@warwick.ac.uk

First received: May 2007

Accepted: November 2007 


\begin{abstract}
Characteristic features of the demographic structure of rural areas in the UK include net out-migration of young adults and an older than average age profile. These features pose a labour supply challenge for rural areas. However, many rural areas are experiencing in-migration (from other parts of the UK and overseas) and there has been considerable policy emphasis on capturing the skills of migrants to enhance local economic development. To date, the role of non-UK migrants in rural areas has received relatively little attention. This paper discusses the impact of recent growth in the numbers of international migrants on the economy and labour market of rural areas and considers the opportunities and risks for rural development posed by increasing reliance on non-UK migrants in the workforce.
\end{abstract}

Key words: Migration (J61); Skills (J24); Labour market (R23); Rural Economic Development (R11)

MENACES POUR LE DEVELOPPEMENT RURAL ET L'OFFRE DE MAIN D'OEUVRE AU Royaume-Uni : LE ROLE DES MIGRANTS NON BRITANNIQUES

Anne E. Green, Maria de Hoyos, Paul Jones et David Owen

Résumé

Les traits caractéristiques de la structure démographique des zones rurales au Royaume-Uni incluent un exode net des jeunes adultes et un profil d'âge plus vieux que la moyenne. Ces traits constituent un défi en matière de main-d'œuvre pour les zones rurales. Toutefois, de nombreuses zones rurales connaissent une migration (d'autres régions du Royaume-Uni et de l'étranger) et les politiciens ont mis l'accent sur la capture des compétences des migrants pour améliorer le développement économique local. À ce jour, le rôle des migrants non britanniques dans les zones rurales a suscité 
relativement peu d'attention. Cet article analyse l'impact de l'augmentation récente du nombre de migrants internationaux sur l'économie et sur le marché du travail dans les $\underline{\text { zones rurales et considère les opportunités et les risques pour le développement rural }}$ du fait d'une plus grande dépendance sur les migrants non britanniques dans la maind'œuvre.

Mots-clés : migration, compétences, marché du travail, développement économique rural

JEL : J61, J24, R23, R11

Entwicklung ländlicher Gebiete und Arbeitskräfteknappheit in Großbritannien: die Rolle nichtbritischer Migranten

Anne E. Green, Maria de Hoyos, Paul Jones and David Owen

\section{$\underline{\text { Abstract }}$}

Zu den charakteristischen Merkmalen der demografischen Struktur der ländlichen Gebiete Großbritanniens gehören eine Nettoabwanderung junger Erwachsener sowie ein von überdurchschnittlich hohem Alter gekennzeichnetes Altersprofil. Diese Merkmale führen in ländlichen Gebieten zu Problemen hinsichtlich des Angebots an Arbeitskräften. Gleichzeitig jedoch ist in zahlreichen ländlichen Gebieten eine Einwanderung (von anderen Gebieten Großbritanniens sowie aus dem Ausland) zu verzeichnen, und seitens der Politik gab es beträchtliche Bemühungen, durch die Anwerbung von qualifizierten Migranten die lokale Wirtschaftsentwicklung zu verbessern. Die Rolle nichtbritischer Migranten in ländlichen Gebieten wurde bisher nur relativ wenig beachtet. In diesem Beitrag untersuchen wir die Auswirkungen des jüngsten Anstiegs der Anzahl ausländischer Einwanderer auf die Wirtschaft und den Arbeitsmarkt in ländlichen Gebieten und erörtern die Chancen und Risiken, die sich durch die zunehmende Abhängigkeit von der Arbeitskraft nichtbritischer Migranten für die Entwicklung ländlicher Gebiete ergeben.

Key words:

Migration

Qualifikation

Arbeitsmarkt

Wirtschaftsentwicklung in ländlichen Gebieten JEL: J61, J24, R23, R11

Desarrollo rural y retos del suministro laboral en el Reino Unido: el papel de los emigrantes no británicos

Anne E. Green, Maria de Hoyos, Paul Jones and David Owen

\section{Abstract}

Algunos de los rasgos característicos de la estructura demográfica de zonas rurales en el Reino Unido son la emigración neta de jóvenes adultos y un perfil de edad más viejo que la media. En zonas rurales estos rasgos se traducen en problemas para la oferta 
de mano de obra. Sin embargo, muchas zonas rurales están experimentando una inmigración (de otras partes del Reino Unido y de ultramar) y se ha puesto especial énfasis político en captar las habilidades de los emigrantes para mejorar el desarrollo económico local. Hasta ahora, se ha prestado relativamente poca atención al papel de los emigrantes de origen no británico en zonas rurales. En este artículo estudiamos el efecto del reciente crecimiento del número de emigrantes internacionales en la economía y el mercado laboral de zonas rurales y analizamos las oportunidades y los riesgos para el desarrollo rural que representa una mayor dependencia de los emigrantes no británicos en la población activa.

Key words:

Migración

Habilidades

Mercado de trabajo

Desarrollo económico rural

JEL: J61, J24, R23, R11 


\section{Introduction}

The workforce in rural areas is ageing faster than in urban areas and typically there is out-migration of young people to urban areas. Those who leave rural areas for higher education are faced with a narrower range and smaller number of knowledge-intensive employment opportunities should they wish to return than are available in metropolitan areas. Many employers in rural areas compete in low value added markets, provide relatively low wages and demand relatively low skills. The term a 'low skills equilibrium' has been used to describe this situation in which an economy is unable to break out of a vicious circle out and achieve higher rates of productivity growth and economic development (WILSON AND HOGARTH, 2003). These typical features pose both an economic development and a labour supply challenge to rural areas. This paper investigates whether changed international migration patterns may present a solution.

One key feature of the processes of globalisation and economic restructuring altering local economic development prospects and development trajectories across advanced economies of the world is the increase in international migration. Until recently much of the academic and policy debate on international migration has been focused on 'world cities' and other urban centres as gateways for international migrants. There has been a relative neglect of international migration flows in the context of rural areas until very recently (COMMISSION FOR RURAL COMMUNITIES, 2007), with a partial exception in relation to their inclusion in seasonal flows in agriculture (BALL, 1987), including as working holidaymakers (HANSON and BELL, 2005). This is despite considerable academic analysis and policy debate on counter-urbanisation in advanced economies, 
where the emphasis has been on internal urban-rural flows and on the characteristics of migration flows by age (and other characteristics).

In the UK, as elsewhere in Europe, southern Africa, North America and Australasia, the economic and labour market impacts of international migrants have risen up the policy agenda and are prominent in political and popular debate. In recent years immigration has been running at historically high levels and the UK has gained population at an increasing rate due to net immigration; net international migration accounted for 246.2 thousand of the 375.1 thousand increase in the UK population between 2004 and 2005 (OFFICE FOR NATIONAL STATISTICS, 2007). Immigration increased steadily during the 1990s and from the mid 1990s asylum flows became a major component of immigration, peaking in the early years of the $21^{\text {st }}$ century. Asylum seekers were spatially concentrated in London and parts of south-eastern England initially, but to relieve the pressure on these areas a dispersal regime was put in place. Urban areas in northern Britain and the midlands contained the main receiving 'cluster' areas for asylum seekers supported by the National Asylum Seeker Support Service. Rural areas tended not to have a large enough volume of spare housing or a sufficiently developed service infrastructure to take large numbers of asylum seekers. Nevertheless, 'gangmasters' are reported to have provided asylum seekers (transporting them long distances from the cities) as cheap labour for rural employers (MERCIA RESEARCH AND STRATEGY, 2006). In the light of concerns that economic migrants were using the asylum system as a means of entry to the UK labour market, in July 2002 the right of asylum seekers to work legally was curtailed (GREEN, 2006a). This illustrates the importance of the legislative and policy context in any consideration of the role of non-UK migrants in the labour market. Here it is salient to note that the UK government espouses a 'managed 
1

migration policy', which makes explicit recognition of the potential role for migration in addressing labour market deficiencies, while at the same time viewing migration as a solution for replacing workers who are retiring and who are not being replaced at the younger end of the workforce due to falling birth rates (STANFIELD et al., 2004).

A further increasingly powerful force behind migration to the UK has been economic integration in the EU and the steady reduction in barriers to the free movement of labour and capital. The expansion of the EU in 2004, and the fact that the UK was one of only three member states (alongside Sweden and Ireland) that chose not to impose large scale restrictions on so-called 'Accession 8' (A8) migrants from the new central and eastern European Accession countries, but instead regulated their access to the labour market via the Worker Registration Scheme (WRS), led to much greater than expected numbers of migrants from 'new' EU member states in central and eastern Europe coming to the UK since 2004. Subsequently, when Bulgaria and Romania (so-called 'Accession 2' [A2] countries) joined the EU in 2007 the UK imposed greater restrictions on migrants from these two countries. Indeed, the scale of recent immigration is such that SALT and MILLAR (2006) have identified Poles as the largest ever single national group of entrants that the British Isles has ever experienced. Three issues concerning this most recent influx of international migrants since 2004 are of particular relevance for this paper: first, the scale and character of the recent in-flows; secondly, the fact that they represent a 'shock' to the labour market (RILEY and WEALE, 2006); and thirdly, that they display a spatial distribution favouring rural areas to a greater degree than previous migration streams (STENNING ET AL., 2006; GREEN ET AL., 2007; BAUERE ET AL., 2007). ${ }^{1}$ 
This paper considers the role of international migrants in the economy and labour market of rural areas in the eastern parts of England. As such it addresses a relatively neglected area of rural economic development, labour market and migration research. It draws on secondary data analysis and on findings of primary research with employers, migrants and stakeholders. It considers the challenges inherent in making best use of migrants' skills to enhance rural development trajectories and then discusses the opportunities and risks for rural development in the medium- and longer-term posed by an increasing reliance on non-UK migrants in the workforce. It does not discuss the detailed dynamics of migration streams, consider the role of social and cultural networks in shaping migration flows and in migrant integration, or address the issue of illegal migration/ working. These are important issues, but are beyond the scope of this paper. Although this paper has a UK focus and different states have different regulatory and institutional frameworks for migration, the generic issues raised regarding labour supply challenges, labour market impacts of migrants and rural economic development are of broader international relevance - for example, for Mexican immigration to the US and for migration from northern Africa to Spain, as well as labour migration from central and eastern Europe to other parts of the EU.

The remainder of the paper is organised into four substantive sections. In the next section labour supply and economic development challenges facing rural areas are outlined in more detail for contextual purposes. First, the demographic context and implications for labour supply are considered; secondly, the changing structure of rural economies is outlined; and thirdly, a taxonomy of labour supply and demand interactions in tight labour markets is presented in order to illustrate the nature of prevailing challenges and the role that migration might play in addressing them. This is a useful 
1

precursor to a focus on the role of non-UK (i.e. international) migrants in the labour market in the following section. Here the estimates of the volume of non-UK migrants are presented, the role of migration in addressing labour shortages and skill deficiencies is discussed, evidence on the scale and character of recent migration flows by industry and occupation from available secondary sources is outlined and the labour market impacts of migrants are assessed. The next section addresses issues relating to making best use of migrants' skills, giving consideration to the perspectives of employers, migrants, labour market intermediaries and public service providers. The paper concludes with an assessment of the role of non-UK migrants in rural labour markets drawing on the evidence presented from eastern England and associated implications for economic development and labour market policy.

\section{Labour supply and economic development challenges facing rural areas}

The demographic context and implications for labour supply

Demographic ageing is one of the foremost challenges facing developed economies (OECD, 2006). As societies move through the demographic transition, fertility rates decline (as child mortality rates fall), and life expectancy increases, so acting in opposite directions to increase the share of older people in the total population. The pace and scale varies between countries and there are also important variations within countries at the sub-national scale. Often inter-regional variations in demographic structure are less pronounced than intra-regional variations between urban and rural areas. Rural areas are typically characterised by out-migration of younger people, and have been so for many years. With the change in the character of the youth labour market and increasing 
participation in post-compulsory education and training, a larger share of young people than formerly are leaving rural areas to take up opportunities for further and higher education in cities. As noted by CHAMPION and SHEPHERD (2006) in recent years the demographic effects of the exodus of young people from rural areas have been exacerbated by counter-urbanisation flows of retirees and middle-aged people, which have led to population growth in rural areas. Moreover, as noted above, traditionally international migrants (characterised by a younger than average age profile) have tended to be attracted to larger cities, so further exacerbating age structure differentials between urban and rural areas.

The rural exodus of young people has led to policy concerns about the quantity and quality of labour market entrants in rural areas. Out-migration reduces the numbers of new entrants to the labour market. Moreover, it is the more ambitious and more qualified young people who are most likely to leave rural areas, leading to an export of skills. This is especially so given recent increases in participation rates in higher education, which are approaching $50 \%$ of the cohort, and the fact that many young people will not return on a permanent basis. Retirees and those in the immediate pre-retirement categories tend to represent only a small net addition to the labour supply. Those in the middle age groups do represent a net addition to the labour supply, but some of these in-migrants to accessible rural areas continue to commute to jobs elsewhere. In more remote and coastal labour markets, seasonal employment and the net in-migration of older people (often with significant care needs) can create a situation of a high dependency rate and low employment rate, with a lack of good employment opportunities and a relatively immobile and poorly qualified resident population of working age (BEATTY AND FOTHERGILL, 2003). There is increased recognition of, and considerable interest, in 
maximising the contribution of in-migrants to the rural economy (COUNTRYSIDE AGENCY, 2003). However, ongoing changes in the demographic profile of rural areas have raised considerable concern about the volume and character of labour supply.

\section{The labour market context}

As noted by WARD (2006), local economic conditions in rural areas are the outcome of local, national and international processes. Since the 1970s these processes have contributed to a continuing marked transformation in the sectoral structure of employment. Traditional industries, especially manufacturing, mining and agriculture, have undergone large job losses. Other industries, most notably in the service sector including financial \& business services, distribution, hotels \& catering, education and health - have experienced job gains (WILSON et al., 2006). Sectoral differentials in employment structures over space have become less pronounced, such that rural economies now have a similar sectoral structure to urban ones (COUNTRYSIDE AGENCY, 2003).

Transformation in the sectoral composition of employment has had implications for the occupational and skills profile of employment. Changes in occupational structure within industries have tended to operate in the same direction. The general picture has been one of rapid growth in numbers and shares of managerial, professional and associate professional occupations associated with higher level qualifications. Employment has grown in personal service and sales \& customer service occupations also, while for skilled trades, operatives and elementary occupations (i.e. manual workers) the picture is one of decline (GREEN and OWEN, 2006). Despite the 'professionalisation' of the 
employment structure, a substantial number of jobs remain at the bottom end of the labour market with limited skill requirements - especially in peripheral rural areas, where the knowledge economy is relatively 'shallow' (HEPWORTH et al., 2004). Moreover, the nature of 'churn' at the lower end of the labour market, coupled with a lower job density in rural than in urban areas leading to more restricted job choice and constraints on opportunities for progression, is such that a preponderance of low skill, low value employment is available in some rural areas.

Until recently, the main emphasis of labour market policy has been on challenges of labour supply and the necessity of ensuring that the (potential) workforce has the necessary skills and attributes to ensure employability in a global economy. As outlined in the Introduction, the skills and work-readiness of young people entering the labour market has been a key focus of policy, but in the context of an ageing population, there is also a need to pay greater attention to workforce development of those already in employment (GREEN and COLLIS, 2006). This is especially pertinent given the historically high levels of employment in England, and relatively low unemployment rates in many rural areas.

However, a focus on labour supply alone is likely to be insufficient to overcome economic problems of low pay and low productivity in some rural areas. Indeed, recent regional economic strategies, particularly in the midlands and northern regions of England, have pointed to the existence of a 'low skills equilibrium' and have identified the necessity of paying attention to labour demand issues for regional and rural economic development (EMDA, 2006; see also WARD et al., 2003). Typical characteristics include a coincidence of relatively low pay levels, a preponderance of poorly qualified workers and 
an under-representation of jobs at the upper end of the occupational hierarchy, reflecting an over-reliance on low knowledge-intensity sectors and a competitive strategy based on low cost. In the face of a lack of demand for higher level skills there is little or no incentive to participate in education and training and raise qualification levels and aspirations. Peripheral rural areas are especially likely to display these characteristics, performing poorly on most economic variables (DEFRA, 2005). This contrasts with a 'high skills equilibrium' situation in which a local economy characterised by a strong demand for high level skills which has a positive effect throughout the supply chain on enhancing the aspirations and actions of individuals with respect to participation in education and training. Hence, raising demand for skills has a key role to play in economic development policies concerned with moving from a situation of 'low skills equilibrium' to one of 'high skills equilibrium'. However from a rural development perspective, it should be noted that low skill jobs are not necessarily associated with low productivity, as exemplified by the food processing sector. With regard to non-UK migrants, a key question is whether they are serving to reinforce the low skills equilibrium' or whether they are using, or can use, their skills in higher value-added activities. We return to this question later.

\section{Labour supply and demand interactions in tight labour markets}

Having highlighted key features of the changing structure of labour supply and demand separately, we now consider their interactions, in order to identify more precisely the nature of labour market and economic development challenges facing rural labour markets and the possible role that non-UK migrants might play in addressing them. We do this with reference to a taxonomy developed by DANIEL et al. (2004) and extended 
by DE HOYOS (2006), which identifies different 'types' of tight labour market where demand for labour is increasing and the supply is struggling to keep pace (see Table 1), in order to identify the possible roles that non-UK migrants might play in creating labour supply challenges.

$<$ Table 1 about here>

Type '1' represents the 'classic' case of a seasonal demand for labour (e.g. for harvesting in agriculture or in certain tourism jobs) which is filled by migrants. Historically, these seasonal demands have been filled mainly by internal migrants or elements of the labour supply seeking short-term work opportunities (including students), and also by international migrants here (e.g. on the Seasonal Agricultural Workers Scheme). Type '2' represents the situation that is likely to occur in rural labour markets as a consequence of either national shortages of people with requisite skills, or in circumstances where differential out-migration of the highly qualified to more attractive opportunities elsewhere has led to a lack of qualified labour for high skilled jobs. It might also be apparent where there is a quantitative shortfall in labour available. In a Type ' 3 ' situation it is likely that migrant labour already represents an important element in labour supply and there is scope for further recruitment of migrants. This situation is especially likely to occur in less skilled positions in sectors such as food processing and packing, catering, etc. Opportunities for non-UK migrants in a Type ' 4 ' situation are likely to be similar to those in Type ' 2 "; (the difference being that in '4' migrants are needed to fill vacancies generated by replacement demand in declining sectors). In a Type ' 5 ' situation, there is a role for highly skilled migrants to fill specific skill gaps. 
Hence, there is a role for non-UK migrants in rural areas at either pole of the skills continuum and in both sectors experiencing employment growth and decline. In the next section we present empirical evidence on the scale and character of migration, the employment of non-UK migrants (including which of the 'types' of role identified in Table 1 they are fulfilling) and associated labour market impacts.

\section{The role of non-UK migrants in the labour market}

\section{The scale and character of migration}

Ascertaining the scale of migration to the UK and, more particularly, the numbers, economic contribution and labour market impacts of non-UK migrants at local level is hindered by the fact that no single data source provides a comprehensive and up-to-date picture. Different data sources adopt different definitions, and relate to different time periods and geographical areas, so providing a 'partial' view (REES and BODEN, 2006; GREEN et al., 2007). The shifting nature and composition of the migrant population and uncertainty about length of stay (especially given the lack of information on individuals leaving the UK), renders estimation of the size of the migrant population in any local area difficult. These considerations need to be borne in mind information on non-UK migrant volumes presented in this section.

We know from analyses of 2001 Census data that the largest volumes of non-UK migrants (i.e. people born outside the UK) are concentrated in the major urban areas, but this provides no indication of trends in migration. We turn to an administrative source National Insurance number (NINo) registrations for overseas nationals - to generate an 
updated and more complete picture of the overall increment to the workforce in England by foreign nationals. ${ }^{2}$ There has been a marked increase in NINo registrations by overseas nationals in recent years: 579 thousand in 2005/6 compared to around 309 thousand in 2002/3. Table 2 shows the change in the volume and pattern of NINo registrations by overseas nationals across England using the DEFRA urban-rural categorisation of districts. Most registrations occur in Major Urban Areas, but their dominance has declined from 64 per cent of the England total in 2002/3 to 55 per cent in 2005/6. A clear negative association is apparent between percentage increase in registrations and urban density. This is indicative of a relative shift in the spatial distribution of non-UK migrants towards more rural areas, especially from 2004 onwards, as central and eastern European migrants entered the UK in large numbers.

It is appropriate here to emphasise the importance of the distinction between the absolute volume of migrants and the growth rate in numbers of migrants. It is clear that urban areas have seen the largest volumes of new migrants, but this is historically a wellestablished pattern. Arguably, cities with a long background of large and diverse non-UK born communities have more 'absorptive capacity' in accommodating further waves of migration. Rural areas have historically been characterised by much less diverse populations and a less well developed infrastructure for migrant integration. In such areas a relatively large influx of migrants from a low base may be perceived as posing a greater challenge for labour market integration and economic development. This challenge is not unique to the UK. In the USA, for example, immigrants are increasingly dispersing beyond traditional 'gateway' metropolitan areas to areas which previously have not experienced much migration (MARROW, 2005), with particular implications for rural economies and the demography of rural areas (PARRA and PFEFFER, 2006). 
$<$ Table 2 about here>

Here, however, the character of the migration (i.e. whether it is temporary or permanent) and the characteristics of migrants are of particular importance. We do not know with any certainty the extent to which migration is temporary or permanent, since (as noted above) we know little about emigration flows from the UK. However, as discussed in the next section, whether migration is temporary or permanent is likely to shape migrants' attitudes towards skill development and integration and have implications for skills and learning provision. From analyses of the LFS and administrative data sources we know that migrants are concentrated in particular industries - such as health, hotels \& catering and certain parts of manufacturing (often in sectors experiencing overall employment decline but with replacement demand requirements). Analysis of WRS data highlights the concentration of central and eastern European migrants in agriculture, food processing, manufacturing and hospitality and catering (COMMISSION FOR RURAL COMMUNITIES, 2007). Occupationally, migrants are concentrated in certain professional occupations (notably as health professionals and business \& public service professionals) and also in elementary, operative and caring personal service occupations. Given the changing importance of different migration 'routes' there is some evidence away from a 'bi-polar' occupational distribution of migrants towards a greater share in less skilled occupations. This tendency is likely to be especially pronounced in rural areas, given that Work Permit approvals are particularly concentrated in urban areas and that WRS registrations are skewed more towards rural areas than previous migration streams. 


\section{The rationale for migration}

The earlier discussion of labour supply and demand interactions highlighted the role of migration in meeting shortfalls in the quantity and quality of labour. Here we consider the economic rationale for migration, first from the demand-side (i.e. the employer perspective) and secondly from the supply-side (i.e. from the migrant perspective), as a precursor to a review of the labour market impacts of migration in the next sub-section, and the following discussion of how and whether best use is being made of migrant skills to foster rural development.

As noted above, employers may recruit migrant labour for a number of reasons including to fill temporary or seasonal vacancies, to fill vacancies for which there are not enough other applicants, and to perform jobs requiring specialist skills not available in the UK. From an employer perspective there may be possible economic benefits (especially in the short-term) of recruiting migrants, including first and foremost addressing labour shortages and skills deficiencies. Some employers may save on costs of training by recruiting staff with the necessary skills. They might also benefit from reduced pressure on wages if workers from countries with lower wage levels are willing to accept lower pay than UK-born workers and if stronger competition for jobs leads to less upward pressure on wages. There might also be productivity gains from employing migrants who tend to be younger on average than indigenous workers and to have better educational qualifications.

From the migrant perspective, the main economic rationale for migration is the return that might be realised in the short- or medium-term. In monetary terms, economic 
migrants seek to earn more in the UK than in their home country. As outlined below, migrants' temporal, spatial and labour market aspirations are crucial in determining whether, and to what extent, they wish to develop their skills while in the UK. A transient migrant is likely to have a very different attitude to learning and skills development than a migrant who intends to settle in the UK in the medium- or long term. Likewise, a migrant who views his/her current labour market position as a positive step in a broader career trajectory (in the UK or elsewhere) is more likely to have a positive attitude towards skills development than one who does not. From 2007, overseas students are allowed to work in the UK for a year after graduation, and thus staying to work in the UK will be an increasingly common choice for those who wish to gain employment experience, and some may choose to pursue a career in the UK.

The impact of non-UK migrants on the labour market

Migration may be beneficial to the national, regional and local economy if by addressing labour shortages and skills deficiencies it has a positive effect on output. A recent study focusing on the East Midlands estimated that in 2005 people born outside the UK contributed 9.6 per cent to the value of output in the East Midlands, with those entering the UK since 1992 contributing around 4 per cent to the value of regional output and post 2001 migrants contributing over 2 per cent to the value of regional output (GREEN et al., 2007). The migrant contribution to GVA was highest in Hotels \& Restaurants, Manufacturing (which includes food processing) and Health \& Social Work sectors. Lack of GVA data by industry at sub-regional level precludes estimation of the migrant contribution to GVA for rural areas; in any local area the migrant contribution to GVA 
could be higher/ lower than the regional estimate.

Possible labour market costs for the UK-born population associated with recruitment of labour migrants from outside the UK include exertion of downward pressure on wages, a reduction in employment rates amongst other groups in the labour market as employers use migrants to replace UK-born workers (i.e. a displacement effect), an associated increase in the unemployment rate, and a lower probability of some groups - especially the most vulnerable (i.e. those with poor skills/ in low wage segments of the labour market) - finding sustainable employment in the face of increased competition from migrants. To date, empirical analysis of Labour Force Survey for the UK by DUSTMANN et al. (2005) has found no evidence that immigration has effects on employment, participation, unemployment or wages at aggregate level. National scale analyses by the Department for Work and Pensions (PORTES and FRENCH, 2005; GILPIN et al., 2006) have found no discernible statistical evidence to suggest that migration from A8 countries has been a contributor to the rise in claimant unemployment in the UK. The overall conclusions of previous analyses are that in aggregate the impact of migration from A8 countries has been modest, but broadly positive. However, it is possible that the impact of migration on the labour market may vary both over time and across space.

Recent analyses by GREEN et al. (2007) focusing on the East Midlands found no statistically significant evidence that migrants dampen wage growth. The role of the National Minimum Wage in increasing/ maintaining pay in less skilled occupations is important here. Evidence of employment displacement of UK-born workers was found in certain 'migrant dense' sectors (including food processing) and occupations (notably operative and elementary occupations), but it was unclear whether such displacement 
1

was voluntary or involuntary. Analyses based on LFS data revealed that a disproportionately large number of the unemployed came from migrant dense industries and occupations, but this association is most likely the result of greater 'churning' between employment and unemployment in these sectors and occupations as opposed to a systematic effect arising from migrant density per se. Transitions of UK-born workers out of migrant dense occupations via unemployment have increased notably in the last two years (at a time of increasing numbers of A8 migrants recorded by the WRS and increasing NINo registrations by overseas nationals), especially when compared to other non-migrant dense occupations. It is clear that it is those UK-born workers lacking qualifications and working in less skilled occupations, who are most vulnerable to a range of factors relating to labour market change in any case, are the most likely to feel the negative impacts of migration. Locally, there is a positive association between the rate of increase in claimant unemployment and overseas NINo registrations as a percentage of employment. Since migration is inherently spatial, it is at the local level that effects are most likely to be felt, and anecdotal evidence suggests that the recent rapid increase in migration is associated with an increase in unemployment rates in some geographically peripheral labour markets where distance limits access to employment opportunities (GREEN, 2006b). It is important to note here that it is still relatively early to make assessments of the impacts of A8 migrants. The scale and character of flows may change over time, as might their impacts. Without the benefit of hindsight, we are unable to assess whether recent circumstances are exceptional.

More broadly, an influx of migrant workers may affect the way in which labour market operates, specifically in relation to changing routes of access to jobs. Typically, migrants are recruited either via employment agencies and gangmasters or via word of mouth 
within migrant networks, such that certain jobs may become institutionalised as 'migrant jobs'. In turn, this may result in reductions in vacancies notified to Jobcentre Plus (the UK government employment service), so impacting on individuals seeking employment openings via that route.

\section{Making best use of migrants' skills for rural development}

As well as helping to ameliorate a numerical shortfall in workers available and willing to undertake certain jobs, potentially use could be made of migrants' skills to enhance rural development trajectories. There is no comprehensive information available on the qualifications and work experience of non-UK migrants (although some insights may be gained from information collected in household and migrant surveys, as indicated below) and even when information is available there are often difficulties in translating migrants' qualifications into UK equivalents. Despite these difficulties, it is evident that recent migrants from central and eastern Europe, in particular, are better qualified than the indigenous population (ZARONAITE and TIRZITE, 2006). Indeed, a consistent finding from previous research is that many migrants tend to be working below their skills levels (ANDERSON et al., 2006). In this section we assess the prospects for development of migrants' skills for the benefit of the rural economy by considering employers' and migrants' perspectives in turn, before moving on to outline current skills and learning provision and barriers to participation in learning.

What are employers' skills requirements?

The typology of tight labour markets presented in Table 1 is suggestive of the likelihood 
1

of variations in employers' skills requirements in relation to migrant workers. Employers who resort to employing migrant labour for low skill work because of a lack of people locally to fill vacancies may have little interest in making full use of the skills of migrant labour: a willingness to work may be more important than specific skills. On the other hand, employers recruiting migrant labour to fill specific skill-shortage vacancies will have an interest in maximising use of migrants' skills.

These differences are borne out in a 3-fold typology of employer attitudes towards employing migrant workers developed in a research study examining employers' perceptions of migrant workers (LEARNING AND SKILLS COUNCIL, 2006). The first category of 'reluctants' had negative attitudes towards migrant workers, employing them as an option of last resort when other recruitment channels had been exhausted. Such employers are unlikely to go out of their way to invest in development of migrants' skills beyond minimum legislative and business imperatives. Conversely, employers categorised as 'advocates' were characterised by a positive attitude towards migrant workers. Such employers were most likely to seek to develop migrants' skills. Between these two more extreme positions, the majority of employers fall into the moderate 'pragmatists' category, characterised by positively balanced views towards hiring migrant workers, viewing them dispassionately as a cost-effective commodity. For the 'pragmatists', the main advantage of hiring migrant workers is that they were perceived as having a stronger and more positive work attitude and ethic than UK-born workers. This highlights that the issue that 'willingness to work' may be more important than specific skills - a fact underlined by other research with employers (DENCH et al., 2006; ANDERSON et al., 2006) which revealed that some employers prefer migrants (especially eastern European) to British workers, because they are perceived to be better 
employees and have a better attitude to work. A survey by the Chartered Institute of Personal Development (2005) providing a comparison of employers' ratings of migrant workers compared to other potential recruits (such as lone parents, those with low skills, the over 50s, the disabled and long-term claimants of incapacity benefits) found that migrants were the most highly rated category for productivity, adaptability, quality of work and potential, and were second most highly rated for reliability, absence, customer service and teamwork. This suggests that migrants compete strongly in recruitment channels to lower skilled occupations, and indicates the potential challenge to UK government initiatives to increase the employment rate of 'excluded' groups.

Despite the recognition of greater 'potential' of migrants than potential recruits from the core jobless groups, it is clear that first and foremost it is an 'attitude gap' (especially on the part of younger UK workers who tend to be viewed as unmotivated and unwilling to take low or unskilled jobs) rather than a 'skills gap' that employers see migrants as filling. This suggests that in current circumstances there is little likelihood that migrants' skills will be maximised to reap broader economic development benefits.

Employers' perceptions of migrant workers themselves underscore this point, as a 3-fold typology of migrant workers developed from research with employers (LEARNING AND SKILLS COUNCIL, 2006) illustrates. First, there are 'economic migrants' who are often low-skilled workers aiming to stay in low-skilled roles, attracted by the relatively higher pay found in the UK compared with their origin country. Generally, they are perceived as having short-term plans or opportunistic ideas regarding employment and want to make money easily and quickly. They are unlikely to integrate strongly into the UK workforce, especially if working in migrant dense sectors and occupations in remote rural areas. 
From an employer perspective, training for such migrants may well be seen as a cost to be avoided. A second group of migrant workers identified by employers are 'aspiring migrants'. Typically, this group comprises students and skilled workers taking unskilled work in the UK while improving their English language abilities and/or gaining other relevant qualifications so that they can pursue their true career path - either in the UK, their country of origin or elsewhere. For this group of migrants employers might see the onus of improving English language skills on the workers themselves, since they would be the prime beneficiaries. Arguably, however, this group may be able to use their skills to contribute more broadly to business success and economic development in the UK. Thirdly, there are 'global migrants' who take skilled positions in the UK so addressing skills deficiencies. Members of this group are typically concentrated in professional positions and in metropolitan labour markets - especially London.

What are migrants' aspirations?

As the typology of migrants based on employers' perspectives indicates, there is no such thing as a 'typical' migrant. Research with central and east European migrants (ANDERSON et al., 2006) has reiterated that many trade-off low-skilled work and poor conditions for better pay than in the their home country (i.e. the classic 'economic migrant' position) or for other benefits, such as learning English (i.e. the 'aspiring migrant' category identified above). For many of these migrants working conditions are tolerable only because they are temporary. Even within these broad categories of migrants there is likely to be some differentiation in motivations and aspirations, depending on age, family ties, previous work experience and skill level (MACKAY and WINKELMANNGLEED, 2005). 
A detailed study on 'The Dynamics of Migrant Labour in South Lincolnshire' (ZARONAITE and TIRZITE, 2006), involving primary research with non-UK migrants, reiterated these points. At one level all migrants seek to improve their quality of life either solely in monetary terms, or also by broadening their range of experiences and skills. Turning explicitly to study aspirations, 39 per cent of migrants surveyed wished to improve their English by taking ESOL (English for Speakers of Other Languages) courses and 32 per cent wanted to attend IT courses. It is salient to note here that English language and computing skills are both regarded 'key skills' for progressing in the UK labour market. Beyond this, many migrants wanted to gain equivalent UK qualifications in their profession.

Whether, and how important it is for these aspirations to be achieved, depends in part on migrants' future plans. Nearly a quarter (23 per cent) of migrant workers responding to the migrant survey undertaken for 'The Dynamic of Migrant Labour in South Lincolnshire' study planned to stay in the UK permanently, while a further quarter had not yet decided (citing reasons of conditions of work, accommodation and issues relating to bringing children to the UK) for their uncertainty. Just under a fifth indicated that their stay in South Lincolnshire was 'temporary' and a further 14 per cent cited stays of up to 2 years. Of course, whether these plans are fulfilled remains to be seen.

Assessment of current and likely future skills needs

Migrants' skills sets are often highly individualised and specialised, and this needs to be recognised in discussions of skills development and learning provision. Current learning 
needs of migrants are primarily focused on language; at least a basic understanding of the English language is important for nearly all jobs (especially given the growth of service jobs with a customer facing element) and is fundamental to broader labour market integration. 'Aspiring migrants' are keen to improve their English and to gain other qualifications - perhaps to achieve promotion and/or to enhance prospects of obtaining a permanent job. Here primary research in rural areas of eastern England has highlighted that there are often information/knowledge deficits regarding the relevance and availability of learning opportunities available.

A study of EU migrant workers in southern Lincolnshire involving interviews with stakeholders concluded that, in the short-term, language training (ideally tailored to the immediate needs of the work environment and the more general social context) should be addressed before or alongside any other learning needs of migrants are considered (GREEN et al., 2006). In the short-term, other training needs are likely to relate to health and safety requirements. Thereafter, depending on migrants' aspirations and knowledge base, it may be appropriate to address technical, business and managerial skills needs.

\section{Barriers to learning and current provision}

Even if migrant workers are highly motivated and wish to enhance their skills, and are aware of provision available, conditions of working may impose barriers to learning. Employers play an important role in facilitating access to learning opportunities. Given the fact that migrant workers may not live near their workplace and may move between workplaces on a relatively frequent basis, there may be transport barriers in accessing learning opportunities. Moreover, because of the long hours (and variable shift patterns) 
worked by many migrants, they may be too tired to take full advantage of learning opportunities available. Hence, the wider structural environment has a massive impact on the effectiveness of learning initiatives.

Previous research (GREEN et al., 2005) has highlighted issues of flexibility, individualisation and specialisation in meeting the needs of migrants - all of which have cost and resource implications. Funding is a key constraint on learning provision and delivery, and will become increasingly so given plans to withdraw automatic funding for ESOL courses from 2007/8 in England - so placing the onus on employers and individuals to fund learning. To date, a common concern of those concerned with delivery is that the greater costs of training provision in rural than in urban areas are not recognised in nationally administered funding formulae. Moreover, the sheer numbers of migrants coming to local areas over a relatively short time period places a severe constraint on available capacity/ resources. Existing problems may be exacerbated by increasing inflows/ churning of migrants. Changes in the profile of migrants may also bring challenges, especially in rural areas with a less dense and less well developed migrant integration infrastructure.

\section{Conclusions and implications for policy}

International migrants are playing an increasingly important role in rural economies and labour markets in the UK, some other parts of Europe and the USA. International migration has acted to ease dependency ratios and boost the supply of younger workers (EXPERIAN, 2007). However, from an economic development perspective, there is a fundamental tension between the potential to use their skills in higher value-added 
activities and their role in reinforcing a 'low skills equilibrium' characteristic of many rural labour markets.

One possible benefit from employing non-UK migrants is that they may provide specialist skills not otherwise available to the rural economy and so contribute to rural development. However, a small-scale study of Lincolnshire employers (DE HOYOS, 2006) provides little evidence of the use of non-UK migrants in type ' 2 ' and type ' 5 ' scenarios outlined in Table 1 that would suggest that migrants are filling specialist positions. There are also economic benefits from employing non-UK migrants in operative and elementary occupations requiring low skills levels for which there have been insufficient applicants due to labour shortages or which may have proved hard-to-fill for other reasons (notably because of the nature of the work and working conditions), since they enable some businesses to function to full capacity where otherwise they would not be able to do so. Evidence from studies of migrant workers and rural labour markets in the east of England indicates that non-UK migrants are mainly used in the type ' 1 ' and type ' 3 ' scenarios outlined in Table 1. Given that migrants tend to be relatively young and often relatively highly skilled, they represent 'high quality workers' in 'low-waged work' (ANDERSON et al., 2006). They are valued primarily for their positive 'attitude' and 'work ethic'. In turn they may provide a stimulus for UK-born workers to enhance their productivity.

On the other hand, there is a danger that employers may address labour shortages and skill deficiencies more easily in the short-term by employing migrant labour (whether skilled or unskilled) than by attracting non-employed local people from core jobless groups, training their own staff or by capital investment, and in so doing, perhaps 
undermine the long-term viability of their businesses. This is a particular challenge for rural areas characterised by a 'low skills equilibrium': it is possible resorting to use of migrants as a short-term 'fix' may reinforce this equilibrium. It is important that utilisation of migrant workers is not to the detriment of investing in the indigenous skills base and the ability to respond to future economic change through innovation. Reliance on migrant labour may be a source of weakness for some local economies, rather than a source of strength. Given the importance of the interplay of economic, demographic and political trends in the UK and in other potential migrant destination countries and in origin countries, in determining the size and direction of migrant flows, it is questionable whether the attraction of migrants in current volumes to the UK is sustainable (STENNING ET AL., 2006). Moreover, low-value added activities are themselves vulnerable to relocation to locations outside the UK where costs are cheaper.

Research with employers undertaken in late 2006 indicated that some felt that 'aspiring migrants' who remain in the UK are likely to become dissatisfied over the next few years (LEARNING AND SKILLS COUNCIL, 2006). Some could use their skills, combined with an enhanced understanding of UK culture and customs to set up their own businesses to progress on to more skilled jobs. This would be a beneficial outcome for rural development. Moreover, potentially migrants are in a position to provide important global links for the local economy, possibly aiding the internationalisation of businesses. There is strong evidence emerging from the food and drink industry in the East Midlands of a commitment to up-skill at least some migrant workers for long-term benefit (FOOD \& DRINK FORUM, 2004). However, while there are prospects of up-skilling for some 'core' workers, those regarded as 'peripheral' could be left 'trapped' in work characterised by dirty and/or monotonous tasks, long and/or anti-social hours and low pay, and effectively 
assume the attitude of an unwilling UK worker. In both of these scenarios this could result in unskilled positions going unfilled, generating an ongoing demand for economic migrants to fill replacement demand requirements in key industries such as food processing, which are fundamental to local economies of rural areas in areas such as the fenlands of eastern England.

UK-born people with poor skills who are already vulnerable to labour market restructuring and who are most dependent on job opportunities in the immediate local area are most at risk of suffering negative labour market impacts associated with a continuing influx of migrant workers. In order to gain employment it is likely that these individuals will have to overcome their reluctance to take what they view as menial jobs or enhance their skills base in order to compete more effectively for other jobs. There is also a crucial economic development role here in encouraging business development in rural areas and stimulating diversification of the economic base to improve the quality and range of employment opportunities available. Labour demand matters!

As highlighted above, the influx of international migrants on a relatively large scale to some rural areas in the UK (and in some other countries in Europe and beyond) is a recent phenomenon. The fact that the UK opened its borders to migrants from central and eastern Europe in 2004 before the other large EU economies makes the UK experience distinctive in some respects and has contributed to the high volume of migration and speed of change in some local areas. There is a need for ongoing monitoring of trends and impacts, as there is potential for current trends to be reinforced as new arrivals are attracted via migrant networks, as well as for new trends and patterns to emerge as restrictions on labour migration alter and economic circumstances (in both 
migrant origin and destination countries) change. Hence, the conclusions drawn here should be considered provisional at this juncture. Moreover, trends and impacts are likely to be differentiated over space: migrants may play different roles in different rural areas. Hence there is a need for monitoring at local and regional levels, as well as at the national scale.

There is clear need here to improve the information base on international migration in the UK. The Census provides information at a local level but since data is collected decennially, it cannot provide a regularly updated picture. The Labour Force Survey (LFS) and Annual Population Survey (APS) provide a greater range of demographic and labour market information on a more frequent basis, but these sources undercount mobile populations and do not provide robust estimates for less populous geographical areas. Administrative data sources - including NINo registrations by nationality, WRS registration records relating to $\mathrm{A} 8$ migrant workers and information on numbers of Work Permits issued - provide an indication of the scale of labour migration and of the characteristics of migrants at sub-regional and regional level. All of these sources only measure in-migration; information on emigration is lacking. In some local areas surveys have been undertaken, providing information on the demographic characteristics, duration of stay, future intentions, skills, labour market aspirations, etc, of migrant workers (ZARONAITE and TIRZITE, 2006). However, there are doubts about the comprehensiveness of some local surveys, and the information gathered may date quickly. So currently there is considerable uncertainty about even some of the most basic information on numbers of non-UK migrants at local level. 
What is more certain, however, is that the traditional divide in migration studies between internal and international migration (SALT and KITCHING, 1992) is increasingly inappropriate, especially for legal, as opposed to illegal, migrants. With the integration of labour markets in Europe and increasing ease of movement, as testified by the availability of budget air travel from regional airports and cheap coach fares, distinctions between international and internal migration flows are blurring as they become increasingly interrelated.

\section{Notes}

1 Early information on A2 migration suggests that the pattern is less ruraldominated than for A8 migrants (BORDER AND IMMIGRATION AGENCY AND DEPARTMENT FOR WORK AND PENSIONS, 2007).

2 Every overseas national who is legally employed/ self-employed in the UK requires a NINo. NINo registration data cover all labour migrants (i.e. EU citizens - including those from Accession countries who are covered by the WRS), those on Work Permits and others. 


\section{References}

ANDERSON B., RUHS M., ROGALY B. and SPENCER, S. (2006) Fair enough? Central and East European migrants in low-wage employment in the UK, Joseph Rowntree Foundation, York.

BALL R.M. (1987) 'Intermittent labour forms in UK agriculture: some implications for rural areas', Journal of Rural Studies 3, 133-50.

BAUERE V., DENSHAM P., MILLAR J. and SALT J. (2007) 'Migrants from central and eastern Europe: local geographies', Population Trends 129, 7-19.

BEATTY C. and FOTHERGILL S. (2003) The Seaside Economy: The final report of the seaside towns research project, Centre for Regional Economic and Social Research, Sheffield Hallam University.

BORDER AND IMMIGRATION AGENCY AND DEPARTMENT FOR WORK AND PENSIONS (2007) Bulgarian and Romanian Accession Statistics January to March 2007, Home Office, London. http://www.ind.homeoffice.gov.uk/6353/aboutus/Bulgarian_and_Romanian_Acce1.pd f

CHAMPION T. and SHEPHERD J. (2006) 'Demographic change in rural England' in Lowe P. and Speakman L. (eds.) The Ageing Countryside: The Growing Older Population of Rural England. Age Concern England, London.

CIPD (2005) Quarterly Labour Market Outlook, CIPD, London.

COMMISSION FOR RURAL COMMUNITIES (2007) A8 migrant workers in rural areas Briefing Paper. Commission for Rural Communities, Cheltenham and London.

COUNTRYSIDE AGENCY (2003) Rural Economies - stepping stones to healthier futures, Countryside Agency, Cheltenham. 
DANIEL W.W., GREEN A., HOGARTH T. and WESTBROOK S. (2004) 'Tight labour markets in the Highlands and Islands', Project Report prepared for Highlands and Islands Enterprise/ Futureskills Scotland, IER, University of Warwick, Coventry.

DEFRA (2005) Productivity in Rural England. Rural Economic Unit, Defra, London.

DE HOYOS M. (2006) 'Recruitment and retention of labour in Lincolnshire', Working Paper prepared for Lincolnshire County Council 'Skills in Areas Affected by Rural Decline' project, IER, University of Warwick, Coventry.

DENCH S., HURSTFIELD J., HILL D., AKROYD K (2006) Employers' Use of Migrant Labour, Home Office RDS Online Report 04/06, March 2006.

DUSTMANN C., FABBRI F. and PRESTON I. (2005) 'The impact of migration on the British labour market', Economic Journal 115, F234-F341.

EAST MIDLANDS DEVELOPMENT AGENCY (2006) A flourishing region: Regional Economic Strategy for the East Midlands 2006-2020, East Midlands Development Agency, Nottingham.

EXPERIAN (2007) The contribution of migration flows to demographic change in the East Midlands, East Midlands Development Agency, Nottingham.

FOOD \& DRINK FORUM (2004) English for non-English speakers in the food manufacturing sector, Report on a project commissioned by the East Midlands Development Agency.

GILPIN N., HENTY M., LEMOS S., PORTES J. and BULLEN C. (2006) 'The impact of free movement of workers from Central and Eastern Europe on the UK labour market', Department for Work and Pensions Working Paper 29, Corporate Document Services, Leeds. 
GREEN A.E. (2006a) 'Routes into Employment for Refugees: A Review of Local Approaches from London' OECD From Immigration to Integration: Local Solutions to a Global Challenge, OECD, Paris, 189-238.

GREEN A.E. (2006b) 'Interviews with labour market intermediaries and experts', Working Paper prepared for Lincolnshire County Council 'Skills in Areas Affected by Rural Decline' project, IER, University of Warwick, Coventry.

GREEN A. and COLLIS C. (2006) 'Regional and Local Labour Market Prospects: the Importance of Ageing in Workforce Development', Population, Space and Place 12, 323-40.

GREEN A.E., JONES P. and OWEN D. (2007, in press) 'Migrant Workers in the East Midlands Labour Market', Report for the East Midlands Development Agency, IER, University of Warwick, Coventry.

GREEN A.E. and OWEN D. (2006) The Geography of Poor Skills and Access to Work, Joseph Rowntree Foundation, York.

GREEN A.E., OWEN D. and WHITE R.J. (2006) EU Migrant Workers in Southern Lincolnshire, Report on Project commissioned by the Lincolnshire and Rutland Learning and Skills Council, IER, University of Warwick, Coventry.

GREEN A., OWEN D. and WILSON R. (2005) Changing Patterns of Employment by Ethnic Group and for Migrant Workers. Report prepared for the Learning and Skills Council National Office, IER, University of Warwick, Coventry.

HANSON J. and BELL M. (2005) 'Harvest trails in Australia: patterns of seasonal migration in the fruit and vegetable industry', Queensland Centre for Population Research, University of Queensland, Australia.

HEPWORTH M., PICKAVANCE L., and ZIEMANN B. (2004) The Knowledge Economy in Rural England, A Report for DEFRA, Local Futures Group, London. 
LEARNING AND SKILLS COUNCIL (2006) Employer Perceptions of Migrant Workers Research Report, Learning and Skills Council, Coventry.

MARROW H.B. (2005) 'New destinations and immigrant incorporation', Perspectives on Politics 3 (4), 781-799.

MCKAY S. and WINKELMANN-GLEED A. (2005) Migrant workers in the East of England, Report prepared for the East of England Development Agency, Working Lives Research Institute, London Metropolitan University, London.

MERCIA RESEARCH AND STRATEGY (2006) The Extent, Size and Characteristics of the Migrant Workforce in the Vale of Evesham, Mercia Research and Strategy, Evesham.

OECD (2006) Ageing and Employment Policies: Live Longer, Work Longer. OECD Publishing, Paris.

OFFICE FOR NATIONAL STATISTICS (2007) International migration: Migrants entering or leaving the United Kingdom and England and Wales, 2005, Series MN no. 32,

PARRA P.A. and PFEFFER M.J. (2006) 'New immigrants in rural communities: the challenges of integration', Social Text 24 (3), 81-98.

PORTES J. and FRENCH S. (2005) 'The impact of free movement of workers from Central and Eastern Europe on the UK labour market: early evidence', Department for Work and Pensions Working Paper 18, Corporate Document Services, Leeds.

REES P. and BODEN P. (2006) Estimating London's new migrant population: Stage 1 review of methodology, Greater London Authority, London.

RILEY R. and WEALE M. (2006) 'Commentary: Immigration and its effects', National Institute Economic Review 198, 4-9. 
SALT J. and KITCHING R. (1992) 'The relationship between international and internal migration' in Champion, T. and Fielding, T. (eds.) Migration Processes and Patterns: Volume 1 - Research Progress and Prospects, Belhaven Press, London, 148-162.

SALT J. and MILLAR J. (2006) 'Foreign labour in the United Kingdom: current patterns and trends', Labour Market Trends, October, 335-355.

STANFIELD C., CAMPBELL M. and GILES L. (2004) 'The UK workforce: realising our potential', SSDA Research Report 7, SSDA, Wath-upon-Dearne.

STENNING A., CHAMPION A., CONWAY C., COOMBES M., DAWLEY S., DIXON L., RAYBOULD S., and RICHARDSON R. (2006) Assessing the Local and Regional Impacts of International Migration, Department for Communities and Local Government, London.

WARD N. (2006) 'Rural development and the economies of rural areas' in Midgley, J. (ed.) A New Rural Agenda, IPPR, London.

WARD N., LOWE P. and BRIDGES T. (2003) 'Rural and Regional development: The role of the Regional Development Agencies in England', Regional Studies 37, 201214

WILSON R. and HOGARTH T. (eds) (2003) Tackling the Low Skills Equilibrium: A Review of Issues and Some New Evidence, Final report to the Department of Trade and Industry, IER, University of Warwick.

WILSON R., HOMENIDOU K. and DICKERSON A. (2006) Working Futures 2004-2014: National Report, SSDA, Wath-upon-Dearne.

ZARONAITE D. and TIRZITE A. (2006) The dynamics of migrant labour in south Lincolnshire, South Holland District Council, Spalding. 
Table 1: Typology of 'tight' labour markets

\begin{tabular}{|c|c|c|}
\hline Type & Description & Possible role for non-UK migrants \\
\hline 1 & $\begin{array}{l}\text { Where demand is seasonal } \\
\text { resulting in high demand only at } \\
\text { certain times }\end{array}$ & $\begin{array}{l}\text { Short-term migrants for relatively unskilled work } \\
\text { for specific periods }\end{array}$ \\
\hline 2 & $\begin{array}{l}\text { Where demand is strong but } \\
\text { supply is weak }\end{array}$ & $\begin{array}{l}\text { Highly skilled migrant labour in filling skill } \\
\text { shortages } \\
\text { More generally for migrants to plug labour } \\
\text { supply shortfall }\end{array}$ \\
\hline 3 & $\begin{array}{l}\text { Where demand for labour is } \\
\text { strong and supply is also strong }\end{array}$ & $\begin{array}{l}\text { Migrants are already likely to be an important } \\
\text { part of the labour supply in 'migrant dense' }\end{array}$ \\
\hline & $\begin{array}{l}\text { but is unable to keep pace with } \\
\text { demand }\end{array}$ & $\begin{array}{l}\text { sectors and occupations, but there is scope for } \\
\text { employment of further migrant labour }\end{array}$ \\
\hline 4 & $\begin{array}{l}\text { Where demand is sluggish but } \\
\text { supply fails to keep pace }\end{array}$ & $\begin{array}{l}\text { Highly skilled migrant labour in filling skill } \\
\text { shortages } \\
\text { More generally for migrants to plug labour } \\
\text { supply shortfall }\end{array}$ \\
\hline 5 & $\begin{array}{l}\text { Where there are qualitative } \\
\text { changes in the nature of } \\
\text { demand such that supply }\end{array}$ & $\begin{array}{l}\text { Role for highly skilled migrants to fill specific } \\
\text { skill gaps }\end{array}$ \\
\hline
\end{tabular}

Source: based on Daniel et al. (2004); de Hoyos (2006) 
Table 2: Overseas' nationals NINo registrations by urban-rural category, England, 2002/3 to $2005 / 6$

\begin{tabular}{|c|c|c|c|c|c|c|}
\hline \multirow{4}{*}{ Category } & \multirow{4}{*}{$\begin{array}{l}2002 / 3 \\
\text { (000s) }\end{array}$} & \multirow{4}{*}{$\begin{array}{l}2005 / 6 \\
\text { (000s) }\end{array}$} & \multirow{3}{*}{$\begin{array}{r}\% \text { of } \\
\text { England } \\
\text { total, }\end{array}$} & \multirow[b]{2}{*}{$\begin{array}{l}\% \text { of } \\
\text { England }\end{array}$} & \multirow[b]{2}{*}{$\begin{array}{l}\text { Change } \\
2002 / 3 \text { to }\end{array}$} & \multirow[b]{2}{*}{$\begin{array}{c}\text { Change } \\
2002 / 3 \text { to }\end{array}$} \\
\hline & & & & & & \\
\hline & & & & total, & $2005 / 6$ & $2005 / 6$ \\
\hline & & & $2002 / 3$ & $2005 / 6$ & (000s) & (\%) \\
\hline Major Urban & 196.7 & 318.3 & 64 & 55 & 121.6 & 62 \\
\hline Large Urban & 34.9 & 69.9 & 11 & 12 & 35.0 & 100 \\
\hline Other Urban & 37.0 & 77.5 & 12 & 13 & 40.6 & 110 \\
\hline Significant & 19.5 & 48.5 & 6 & 8 & 29.0 & 148 \\
\hline \multicolumn{7}{|l|}{ Rural } \\
\hline Rural-50 & 10.5 & 30.4 & 3 & 5 & 19.9 & 191 \\
\hline Rural-80 & 10.5 & 34.5 & 3 & 6 & 24.0 & 228 \\
\hline ENGLAND & 309.1 & 579.1 & 100 & 100 & 270.0 & 87 \\
\hline
\end{tabular}

40 